\title{
The Effect of Alpha Lipoic Acid on Oxidative Stress in the Rat Experimental Colitis Model*
}

\author{
Ratlarda Deneysel Kolit Modelinde Alfa Lipoik Asit \\ Kullanımının Oksidatif Stres Üzerine Etkisi
}

Özgün Araştırma

Research Article

Alındığı tarih: 03.12.2018

Kabul tarihi: 10.12.2018

Online Yayın tarihi: 26.03.2019

Mustafa Onur Öztan Izmir Katip Çelebi Üniversitesi Çocuk Cerrahisi Kliniği, Izmir, Türkiye

droztan@yahoo.com ORCID: 0000-0003-3696-4090

M.O. Öztan 0000-0003-3696-4090 Tepecik Eğitim ve Araştırma Hastanesi Çocuk Cerrahisi Kliniği, izmir, Türkiye

M.H. Gürsoy 0000-0003-1060-9357 S.K. Özkısacık 0000-0003-3302-727X

M. Yazıcı 0000-0003-1960-7825 Adnan Menderes Üniversitesi, Çocuk Cerrahisi Anabilim Dalı, Aydın, Türkiye

N. Çulhacı 0000-0001-7181-4675 Adnan Menderes Üniversitesi, Patoloji Anabilim Dalı, Aydın, Türkiye

A.B. Karul 0000-0002-3738-2888 Adnan Menderes Üniversitesi, Biyokimya Anabilim Dalı, Aydın, Türkiye

*27. Çocuk Cerrahisi Kongresi'nde sözlü bildiri olarak sunulmuştur.

Cite as: Öztan MO, Gürsoy MH, Özkıcacik SK, Yazıcı M, Çulhacı N, Büyüköztürk Karul A. The effect of alpha lipoic acid on oxidative stress in the rat experimental colitis model. Tepecik in the rat experimental colitis model. Tepecil.
Eğit. ve Araşt. Hast. Dergisi. 2019;29(1):47-55.

\author{
Mustafa Onur Öztan $\oplus^{\oplus}$, Mustafa Harun Gürsoy ${ }^{\oplus}$, Sezen Karaca Özkısacık ${ }^{\oplus}$, \\ Mesut Yazıcı $\odot$, Nil Çulhacı $\odot$, Aslıhan Büyüköztürk Karul $\odot$
}

\section{ABSTRACT}

Objective: Ulcerative colitis is an immonologically mediated chronic intestinal disorder, which is characterized with inflammation, oxidative stress, apoptosis. Our study was aimed to investigate the effects of alpha lipoic acid administered orally or as colonic enema in trinitrobenzene sulfonic acid-induced ulcerative colitis.

Methods: Forty-two Wistar Albino rats were divided into five groups. Intracolonic corn oil was administered in the Control Group. After induction of colitis with trinitrobenzene sulfonic acid, and corn oil via gavage (Sham Group), alpha lipoic acid $200 \mathrm{mg} / \mathrm{kg} /$ day via gavage (ALA Gavage Group), intracolonic alpha lipoic acid $200 \mathrm{mg} / \mathrm{kg} /$ day (ALA Enema Group), and intracolonic corn oil (Corn Oil Enema Group) were administrated. On the eighth day of the study, colonic specimens were evaluated and scored for the presence of macroscopic and microscopic lesions. Results: In the microscopic evaluation, total scores of Sham and Corn Oil Enema Groups were higher than those of the Control Group ( $p<0.05)$. The score of ALA Gavage Group was not different from Control Group ( $p>0.05)$. No significant pathological mucosal changes were detected in ALA Gavage Group, and significantly lower macroscopic scores and blood MDA levels were found when compared to Sham Group $(p<0.05)$.

Conclusion: We determined the positive effects of alpha lipoic acid on histopathological and biochemical parameters in the rat experimental colitis model when administered via gavage. However, we did not determine any positive effect when we administered alpha lipoic acid intrarectally. We can suggest that alpha lipoic acid, when administered orally, may be helpful for prolongation of remission in patients with inflammatory bowel disease, for reducing the frequency of enterocolitis in patients with Hirschsprung disease, and for prevention of necrotizing enterocolitis after further studies.

Keywords: Alpha lipoic acid, antioxidant, colitis, rat, trinitrobenzene sulfonic acid

öz

Amaç: Ülseratif kolit; enflamasyon, oksidatif stres, apoptoz ile karakterize kronik bir gastrointestinal sistem bozukluğudur. Çalışmamızda amacımız, alfa lipoik asiti gavaj ve lavman yolu ile vererek trinitrobenzen sülfonik asit ile deneysel kolit modelindeki antioksidan etkisini araştırmak idi.

Yöntem: Çalışmada, toplam 42 adet Wistar albino sıçan 5 gruba ayrıldı. Birinci gruptaki (kontrol grubu) ratlara 7 gün boyunca günde 1 kez 1 cc intrakolonik mısırözü yağı verildi. Diğer 4 gruptaki ratlarda intrakolonik 25 mg trinitrobenzen sülfonik asit + etanol uygulaması ile kolit oluşturuldu. Kolit oluşturulmasından 1 gün sonra başlanarak 7 gün boyunca ve günde 1 kez olmak üzere; ikinci gruba (Sham grubu) oral yoldan mısırözü, ü̧̈üncü gruba (ALA Gavaj grubu) oral yoldan $200 \mathrm{mg} / \mathrm{kg} / \mathrm{gün}$ alfa lipoik asit, dördüncü gruba (ALA Lavman grubu) intrakolonik $200 \mathrm{mg} / \mathrm{kg} /$ gün alfa lipoik asit ve beşinci gruba (MÖ Lavman grubu) ise intrakolonik 1 cc mısırözü yağı verildi. Çalışma sonunda örnekler histopatolojik ve biyokimyasal parametreler açısından değerlendirildiler.

Bulgular: Toplam mikroskopik değerlendirme skorlarında Sham ve MÖ Lavman grubundaki değerler Kontrol grubuna oranla yüksek saptandı $(p<0,05)$. ALA Gavaj grubundaki değerlerin tümü Kontrol grubuna oranla yüksek saptanmadı ( $p>0,05)$. ALA Gavaj grubunda hiçbir mukozal patolojiye rastlanmazken, Sham grubu ile karşılaştııılıı̆ında makroskopi ve MDA değerlerinde anlamlı düşüklük saptandı $(p<0,05)$.

Sonuç: Çalışmamızda, deneysel kolit modelinde oral alfa lipoik asit kullanımı sonrası histopatolojik ve biyokimyasal değerler üzerinde olumlu etkiler sağladık. Fakat alfa lipoik asiti lavman olarak uyguladığımızda aynı olumlu etkileri göremedik. Bu nedenle oral olarak verilecek alfa lipoik asitin enflamatuvar bağırsak hastalığı olan bireylerde remisyonun devamına yardımcı olabileceğine, Hirschsprung hastalarında postoperatif enterokolit sıklığını azaltabileceğine ve prematürelerdeki nekrotizan enterokoliti önlemede profilaktik olarak kullanılabileceğini düşünmekteyiz. Fakat bu hastalarda kullanılmadan önce insan ve hayvan deney çalışmaları yapılması gerekmektedir.

Anahtar kelimeler: Alfa lipoik asit, antioksidan, kolit, rat, trinitrobenzen sülfonik asit

(C) Telif hakkı T.C. Sağlık Bakanlı̆ı İzmir Tepecik Eğit. ve Arașt. Hastanesi. Logos Tıp Yayınclık tarafindan yayınlanmaktadı.

Bu dergide yayınlanan bütün makaleler Creative Commons Atff-GayriTicari 4.0 Uluslararası Lisansı ile lisanslanmıștr.

(c) Copyright Association of Publication of the T.C. Ministry of Health İzmir Tepecik Education and Research Hospital.

This journal published by Logos Medical Publishing.

Licenced by Creative Commons Attribution-NonCommercial 4.0 International (CC BY-NC 4.0) 


\section{INTRODUCTION}

Ulcerative colitis (UC) is categorized under the name of inflammatory bowel disease (IBD), and it is a chronic disease with relapses and remissions affecting people throughout life ${ }^{(1-3)}$. UC is a chronic bowel disease with the pathological process extending proximally starting from the rectum. It may manifest itself with symptoms such as abdominal pain, diarrhea, purulent feces, and has a variable clinical course with unpredictable relapses ${ }^{(4)}$. In the US, there are approximately one million patients with IBD, and $10-25 \%$ of these are pediatric patients ${ }^{(5)}$. In $20-30 \%$ of adult IBD patients, symptoms are initially observed in childhood or adolescence ${ }^{(6)}$.

Drugs used for treatment include 5-aminosalicylates, corticosteroids, immune system regulators, drugs used for biological and nutritional treatment, antibiotics, and probiotics. UC reduces the quality of life due to the side effects of the drugs used in the treatment together with the susceptibility to infection and bowel cancer ${ }^{(7-9)}$. Since UC is currently a severe threat to public health despite current treatments, it has become a priority to find a suitable agent which can reduce the disease severity.

Alpha lipoic acid (ALA) is a natural short-chain fatty acid containing two sulfur molecules ${ }^{(10)}$. Due to its low redox potential and unique reduction capacity, ALA is responsible for the capture of reactive oxygen species and the reduction of oxidized forms of other antioxidants; it is therefore called the "antioxidant of the antioxidants" (11). Because of this feature, it has been used in preclinical studies and clinical treatment of AIDS, renal lithiasis, ethanol intoxication, brain ischemia, stroke, Parkinson's disease, cutaneous inflammation, diabetic neuropathy, radiation injury, and cataract disease ${ }^{(10-12)}$.

In the light of the previously conducted studies on $I B D$ and $A L A$, our study aimed to investigate the antioxidant effect of ALA in an experimental colitis model in which ALA was administered either by gavage or enema. We hypothesized that ALA, when administered via gavage, will reach the inflammation site via hematogenous route, and reduce inflammation with its systemic effect, and ALA, when given by enema, will directly affect the mucosa through diffusion, and additionally, will have a systemic effect via its hematologic effect.

\section{MATERIALS AND METHODS}

\section{Animals}

The study was conducted after obtaining permission from the Adnan Menderes University Animal Research Ethics Committee in accordance with National Institute of Health Animal Studies Regulation (NIH publication No.86-23, revised 1985). Ten-weekold female Wistar albino rats (250-300 g) were fed with unlimited water and standard pellet food in a standard room temperature, under $65-70 \%$ humidity and 12 hours of light/12 hours of darkness cycle.

A total of 42 Wistar albino rats were used in the study. Rats were divided into five groups and treatments in all groups were continued for seven days;

1) Control Group $(n=8)$ : The rats in Control Group received $1 \mathrm{ml}$ of corn oil (CO) once daily for seven days.

2) Sham Group ( $\mathrm{n}=8)$ : After colitis was induced, $1 \mathrm{ml}$ $\mathrm{CO}$ was given orally once daily for seven days.

3) ALA Gavage Group ( $n=9)$ : After colitis was induced, $200 \mathrm{mg} / \mathrm{kg} /$ day ALA was administered in $1 \mathrm{ml}$ of CO orally once daily for seven days ${ }^{(13)}$.

4) ALA Enema Group ( $n=9)$ : After induction of colitis, $200 \mathrm{mg} / \mathrm{kg} /$ day of ALA dissolved in $1 \mathrm{ml} \mathrm{CO}$ solution was given as a rectal enema once daily for seven days.

5) CO Enema Group ( $n=8)$ : After induction of colitis, $1 \mathrm{ml}$ of $\mathrm{CO}$ was given as rectal enema once daily for seven days.

\section{Creation of TNBS-induced UC}

The 2,4,5-trinitrobenzene sulfonic acid (TNBS) was 
obtained from Sigma Chemicals Inc. and ALA from Solgar Vitamins and Herb Company (Leonia, NJ).

Colitis was induced in all rats except those in the Control Group. The animals had fasted overnight before induction of colitis, and then, their rectums were emptied using the tail reflex. The rats were anesthetized with $5 \mathrm{mg} / \mathrm{kg}$ xylazine and $50 \mathrm{mg} / \mathrm{kg}$ ketamine. A flexible polypropylene catheter with an external diameter of 6 French was placed in the colon with the tip inserted proximally $8 \mathrm{~cm}$ from the anus ${ }^{(14)}$. An amount of $0.63 \mathrm{ml}$ TNBS $(50 \mathrm{mg} / \mathrm{ml}$ ) was dissolved in $0.37 \mathrm{ml}$ of $100 \%$ absolute alcohol. From this mixture, $0.8 \mathrm{ml}$ was delivered into the colon through the catheter ${ }^{(15)}$. The rats were kept in Trendelenburg position for 15 minutes.

On the $8^{\text {th }}$ day of the study, all rats were operated through a midline incision under general anesthesia. The colonic sections of the rats located $10 \mathrm{~cm}$ proximal to the anus were removed for histopathological examination. The colonic sections were opened longitudinally and irrigated with a sterile saline solution. These specimens were graded by the pathologist regarding the presence of a macroscopic lesion. Then, they were placed in formaldehyde solution and sent to the pathology laboratory for microscopic histopathological evaluation. Two milliliters of blood were drawn from all rats for biochemical analysis.

\section{Pathological Examination}

Tissue samples were first fixed in $10 \%$ buffered formalin solution. The samples of colonic tissue were embedded in paraffin after routine tissue preparation, then 4-micron sections were prepared from paraffin blocks and stained with hematoxylin-eosin. The stained preparations were evaluated under light microscopy and changes in the mucosal epithelium, lamina propria and submucosa were scored to determine the severity of the colonic injury.

\section{Evaluation of the severity of the microscopic colonic injury}

The histological injury was assessed by a pathologist who was blinded to the experimental groups, according to the criteria defined by Peran et al. ${ }^{(16)}$. Mucosal epithelium, crypts, lamina propria, and submucosa were assessed and scored as the total microscopic score (Table 1).

Table 2. The assessment of the severity of colonic macroscopic injury.*

\begin{tabular}{ll}
\hline Score & Macroscopic appearance \\
0 & No injury \\
1 & Localized hyperemia (No ulceration) \\
2 & Ulceration (No hyperemia or bowel wall thickening) \\
3 & Ulceration (together with single-site inflammation) \\
4 & Ulceration or inflammation in two or more sites \\
5 & Damage in major regions over $1 \mathrm{~cm}$. \\
$6-10$ & If the injury is present in a site over $2 \mathrm{~cm}$ in size, an additional \\
& 1 point is given for each $1 \mathrm{~cm}$
\end{tabular}

*Maximum score: 10

Table 1. The assessment of the severity colonic microscopic injury.*

\begin{tabular}{|c|c|c|c|c|}
\hline \multirow[b]{2}{*}{ The assessed region } & \multicolumn{4}{|c|}{ Score } \\
\hline & 0 & 1 & 2 & 3 \\
\hline \multicolumn{5}{|l|}{ Mucosal epithelium } \\
\hline Ulceration & Absent & Mild-superficial & Moderate & Severe-Full thickness \\
\hline \multicolumn{5}{|l|}{ Crypts } \\
\hline Mitotic activity & Lower $1 / 3$ & Mild medium $1 / 3$ & Moderate medium $1 / 3$ & Upper $1 / 3$ \\
\hline Mucus accumulation & Absent & Mild & Moderate & Severe \\
\hline \multicolumn{5}{|l|}{ Lamina propria } \\
\hline Vascularity & Absent & Mild & Moderate & Severe \\
\hline Granulocyte accumulation & Absent & Mild & Moderate & Severe \\
\hline Monocyte accumulation & Absent & Mild & Moderate & Severe \\
\hline \multicolumn{5}{|l|}{ Submucosa } \\
\hline Edema & Absent & Mild & Moderate & Severe \\
\hline Granulocyte accumulation & Absent & Mild & Moderate & Severe \\
\hline Monocyte accumulation & Absent & Mild & Moderate & Severe \\
\hline
\end{tabular}

*Maximum score: 27 


\section{Evaluation of macroscopic colonic lesions}

Colonic samples were evaluated according to the criteria defined by Bell et al. ${ }^{(17)}$ regarding the presence of macroscopically visible injury (Table 2 ).

\section{Biochemical Analysis}

\section{Determination of serum malondialdehyde (MDA) levels}

Serum MDA concentrations were determined spectrophotometrically by measuring side products after its reaction with thiobarbituric acid. Each serum sample $(125 \mu)$ was mixed with $250 \mu l$ (0.67\%) thiobarbituric acid and $625 \mu \mathrm{l}(20 \%)$ trichloroacetic acid. This mixture was boiled at $95^{\circ} \mathrm{C}$ for 30 minutes. Then it was cooled in an ice-filled container and centrifuged at 3000 RPM for 10 minutes after adding $1 \mathrm{ml} \mathrm{n}$-Butanol. The supernatant was evaluated against air at $535 \mathrm{~nm}$ on the spectrophotometer. When calculating the MDA concentration, $1.56 \times 105$ mol-1 cm-1 was used as the extinction coefficient of the MDA-thiobarbituric acid complex at $535 \mathrm{~nm}^{(18)}$.

\section{Determination of Serum Catalase Level}

In order to evaluate the catalase in the samples, Buffer A was prepared as $6.81 \mathrm{~g} \mathrm{KH} 2 \mathrm{PO} 4$ in $1000 \mathrm{ml}$ and Buffer $B$ as $8.90 \mathrm{~g} \mathrm{Na} 2 \mathrm{HPO} 4.2 \mathrm{H} 2 \mathrm{O}$ in $1000 \mathrm{ml}$ distilled water. Then 1 part of Buffer $A$ was mixed with 1.5 part of Buffer B. After that, $\mathrm{H} 2 \mathrm{O} 2$ buffer was prepared by adding $85 \mu \mathrm{l}$ of $30 \% \mathrm{H} 2 \mathrm{O} 2$ to $25 \mathrm{ml}$ of this $A+B$ mixture. Blood samples taken into the EDTA tubes were washed three times with cold saline. Hemolysate was prepared with $200 \mu$ l of erythrocytes and $800 \mu \mathrm{l}$ of distilled water. Ten microliter hemolysate was added to $10 \mathrm{ml}$ of buffer $A+B$ in a glass tube. Two $\mathrm{mL}$ of this hemolysate was mixed with $1 \mathrm{ml}$ of $\mathrm{H} 2 \mathrm{O} 2$ and was read at $240 \mathrm{~nm}$ with the spectrophotometer nine times in 15 seconds in $+20^{\circ} \mathrm{C}$ to obtain $\mathrm{A} 1$ value. One $\mathrm{ml}$ of buffer $\mathrm{A}+\mathrm{B}$ was mixed with $1 \mathrm{ml}$ of hemolysate and then evaluated spectrophotometrically to obtain A2 value. Hemoglobin values in blood samples were measured as $\mathrm{gr} / 100 \mathrm{ml}$. The catalase levels were calculated with the $(\log 10(\mathrm{~A} 1 / \mathrm{A} 2)) \times 0.153 \times \mathrm{DF} /$ Hemolysate $\mathrm{Hb}$ formula and expressed as $\mathrm{U} / \mathrm{g} \mathrm{Hb}^{(19)}$.

\section{Determination of Serum Nitric Oxide (NO) Levels}

Samples were deproteinized with $80 \mu \mathrm{l}$ of $30 \%$ ZnSO4 for each $400 \mu \mathrm{l}$ sample. The supernatant was separated by centrifugation. The cadmium was kept in distilled water and then in the Glycine- $\mathrm{NaOH}(\mathrm{pH}$ : 9.2) buffered $\mathrm{C}_{4} \mathrm{SO} 4$ solution for 1-2 minutes. It was then rewashed with Glycine- $\mathrm{NaOH}$. The $200 \mu$ l deproteinized supernatant was incubated with $200 \mu \mathrm{l}$ Glycine- $\mathrm{NaOH}, 400 \mu \mathrm{l} \mathrm{H2O}$ and 20-30 mg cadmium for $90 \mathrm{~min}$ and centrifuged. After centrifugation at $10000 \mathrm{rpm}$ for 10 minutes, the supernatant is collected. One-hundred $\mu \mathrm{l}$ of the supernatant, $50 \mu \mathrm{l}$ of $\mathrm{N}$-Naphylene diamine and $50 \mu \mathrm{l}$ of sulfonamide were added onto plate, and incubated for 45 minutes. It has been read against the standard prepared with NaNO2 MA:69.0 at $540 \mathrm{~nm}$ wavelength ${ }^{(20)}$.

\section{Statistical analysis}

Fitness to normal distribution in the groups was tested with Kolmogorov-Smirnov test. All results were presented as mean \pm SD (standard deviation) and median (minimum-maximum) according to the normal distribution. Data were analyzed by KruskalWallis ANOVA and Dunn multiple comparison posttests. Statistical analysis was performed using GraphPad InStat 3.0 (San Diego, CA, USA) and SPSS 16.0 statistical software. A p-value less than 0.05 was considered statistically significant.

\section{RESULTS}

\section{Pathological Examination}

\section{Comparison of Microscopic Examination Total Scores}

Table 3 shows the histopathological examination scores of the colon. In the statistical evaluation of the total score of the microscopic examination, sig- 

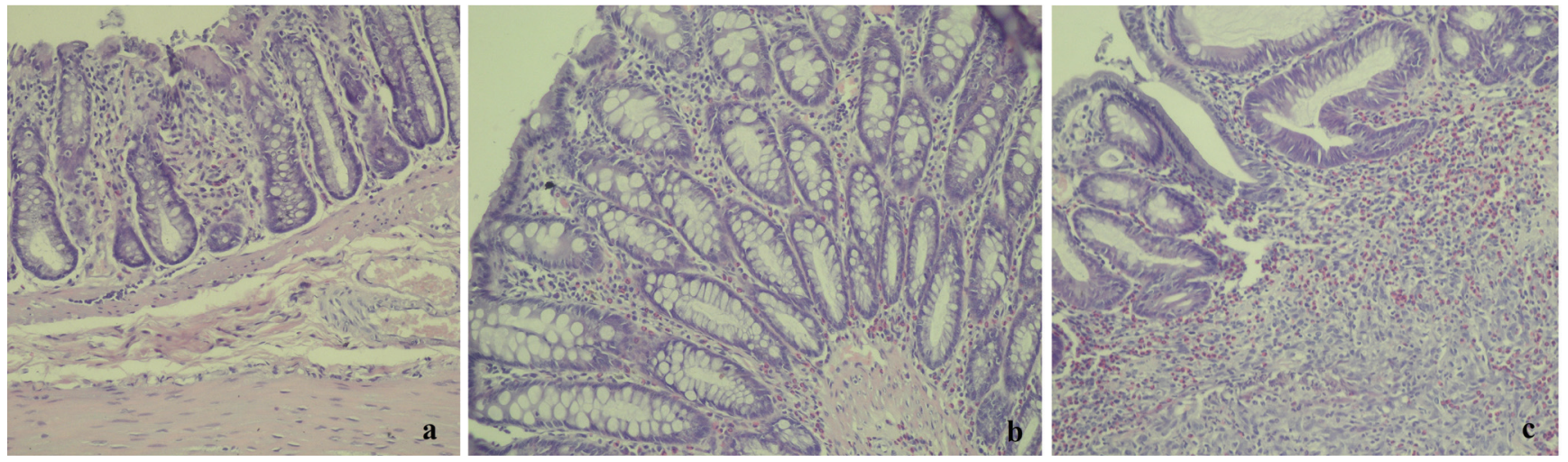

Figure 1. Microscopic assessment of the mucosa, crypts, lamina propria, and submucosa (a: Mild mononuclear and PNL cell infiltration is seen (H \& E stain, x200 magnification). b: Inflammation extends to the lamina propria and beyond (H \& E stain, x200 magnification). c: Full thickness inflammation is seen ( $H$ \& E stain, $x 200$ magnification).

Table 3. The comparison of macroscopic and microscopic assessment scores.

\begin{tabular}{lcc}
\hline Group & The macroscopic score & The microscopic total score \\
\hline Control & $0.00 \pm 0.00$ & $2.38 \pm 0.91$ \\
Sham & $2.63 \pm 3.46^{\mathrm{a} 1}$ & $11.38 \pm 6.16^{\mathrm{a} 1}$ \\
ALA Gavage & $0.56 \pm 0.53^{\mathrm{b}}$ & $6.33 \pm 1.73$ \\
ALA Enema & $1.78 \pm 2.28$ & $10.22 \pm 6.40^{\mathrm{a} 2}$ \\
Corn Oil Enema & $0.88 \pm 1.36$ & $11.38 \pm 5.10^{\mathrm{a} 1}$
\end{tabular}

${ }^{a}$ : Significantly different compared to Control Group $\left(^{a 1}: p<0.05,{ }^{a 2}: p<0.01\right)$. ${ }^{b}$ : Significantly different compared to Sham Group ( $\left.p<0.05\right)$.

nificant values were found in Sham Group compared to Control Group $(p<0.01)$. The total score in the ALA gavage group was meager, and there was no statistical difference between this value and the value found in the Control Group ( $>0.05)$. Significantly high values were observed in ALA Enema $(p<0.05)$ and CO Enema $(p<0.01)$ Groups when compared to Control Group. Figure 1 shows the three images in which the inflammation increases from mild to severe.

\section{Comparison of Macroscopic Views}

No lesions were found in the macroscopic evaluation of Control Group (Table 3). There was a statistically significant difference between Control and Sham Groups in the evaluation of macroscopic views $(p<0.05)$. In the ALA Gavage Group, statistically significantly low values were obtained compared to Sham Group $(p<0.05)$. Figure 2 shows macroscopic images from four groups.
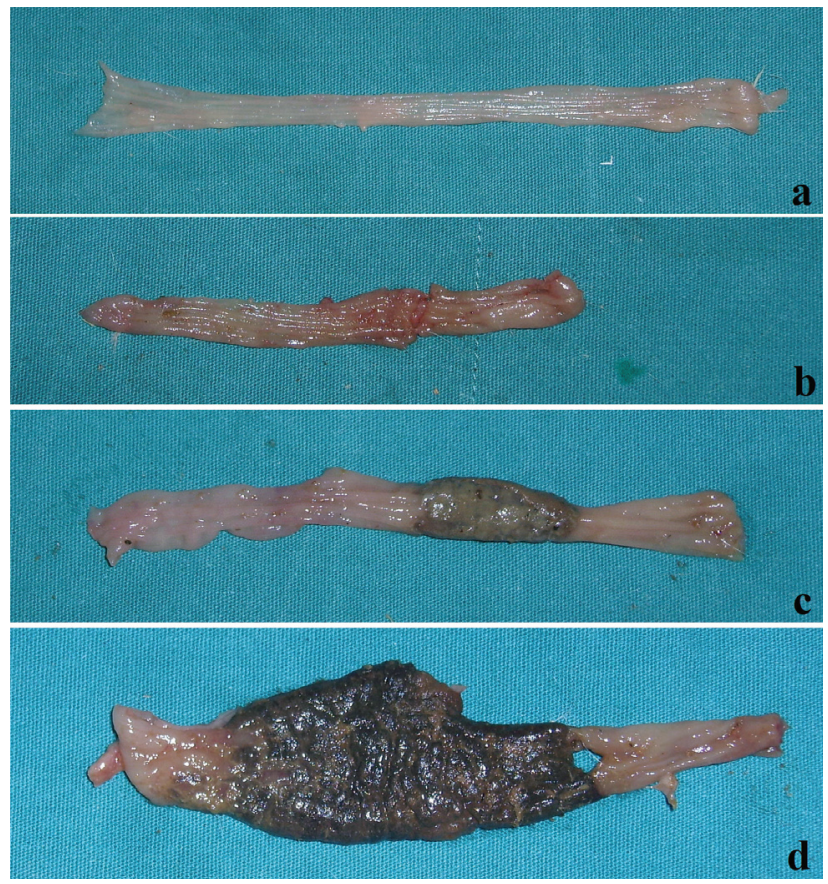

Figure 2. The comparison of macroscopic views. (a: Normal colonic tissue obtained from Control Group is observed (Score: 0 ). b: The macroscopic score of a sample in ALA Gavage Group was measured as 1 c: Inflammation and ulceration is observed in the colon of a rat in the ALA Enema Group (Score: 3 ) d: 4-cm-long ulcerated colonic tissue obtained from a rat in Sham Group is observed (Score: 8).

Table 4. The comparison of serum oxidation parameters.

\begin{tabular}{lccc}
\hline Group & MDA (nmol/ml) & Catalase (U/gr Hb) & NO (nmol/L) \\
\hline Control & $0.58 \pm 0.03$ & $1.13 \pm 0.21$ & $7.83 \pm 0.69$ \\
Sham & $0.86 \pm 0.42 \mathrm{a} 1$ & $1.12 \pm 0.29$ & $9.47 \pm 2.40$ \\
ALA Gavage & $0.54 \pm 0.05 \mathrm{~b}$ & $1.03 \pm 0.27$ & $8.33 \pm 0.96$ \\
ALA Enema & $0.62 \pm 0.04$ & $1.59 \pm 0.46 \mathrm{c}$ & $9.55 \pm 1.53$ \\
CO Enema & $0.59 \pm 0.06$ & $1.42 \pm 0.39$ & $7.66 \pm 0.97$ \\
\hline
\end{tabular}

mpared to Sham Group $(p<0.05)$. 


\section{Biochemical Results}

Table 4 shows serum MDA, NO, and catalase values. Serum MDA levels were found to be higher in the Sham Group compared to Control Group $(p<0.05)$. MDA level was found to be lower in ALA Gavage group compared to Sham Group $(p<0.05)$. The values in the $\mathrm{CO}$ enema group were significantly lower than those of Sham Group $(p<0.05)$. NO levels were not statistically different between groups ( $p>0.05)$.

\section{DISCUSSION}

The rat TNBS colitis model is a widely used test model to mimic UC in humans and to investigate novel pharmacological approaches for the prevention of UC. In this study, we investigated the role of ALA in colitis induced by TNBS in vivo. Our results showed that oral administration of ALA inhibited TNBS-induced colon inflammation and injury; however, we were unable to detect similar effects of ALA when given by the rectal route.

Although the pathogenesis of IBD has not been fully understood, it is accepted that genetic, and environmental factors, microbial flora, barrier dysfunction, and immunological disorders have effects on its pathogenesis ${ }^{(3,21-23)}$. Current clinical and experimental studies have shown that impaired intestinal barrier function allows passage of harmful molecules into the lamina propria under the colonic mucosa and inducing intestinal inflammation through continuous stimulation of the mucosal immune system ${ }^{(24,25)}$. For this reason, further studies are conducted on anti-inflammatory treatments, which may be alternative or supportive of the current therapies used in recent years.

In animal studies, ALA has been found to affect $\mathrm{Na} / \mathrm{K}$-ATPase and Ca-ATPase activities in erythrocytes, to reduce plasma ethanol level, to have positive effects on locomotor activity, to reduce the severity of hippocampal cell injury and GSH levels in brain, to decrease skin inflammation, to enhance nerve blood flow and conduction, to reduce cataract formation, and to lessen the severity of inflammation in airways in asthma. In studies among humans, it has been shown that ALA increases endogenous antioxidant levels, has positive effects on $T$ helper lymphocytes, and reduces the amount of lipid peroxidation products ${ }^{(10,11)}$. After oral administration, it is highly absorbed in the form of lipolysis, metabolized by the liver, and released into the systemic circulation. Although ALA is widely used as a dietary supplement, it also has an intravenous form for treatment.

Experimental colitis induced by TNBS in ethanol by rectal route has been a conventional method used for years ${ }^{(26)}$. After ethanol breaks down the mucosal barrier, TNBS creates dose-dependent ulceration and inflammation. In their study, Jurjus et al. (27) mentioned the similarity between TNBS colitis model and human colitis disease and pointed out that it was an advantageous model in the development and testing of drugs that can be used in the treatment of this disease. In the study of Torres et al. (28), TNBS colitis was examined, and histopathological findings were revealed. In their study, ulceration and desquamation of mucosal epithelium, polymorphonuclear cell infiltration in lamina propria, edema, transmural inflammation, and various degrees of lymphocyte infiltration were observed. In addition to those findings, increased mucus secretion in goblet cells and cryptitis were also observed. In our study, high scores regarding the presence of microscopic and macroscopic lesions together with serum MDA levels in Sham Group compared to Control Group revealed that our experimental model and our results were valid.

One of the first studies on the use of ALA in an experimental colitis model belongs to Kolgazi et al. ${ }^{(29)}$. In their study, after creation of TNBS colitis, $25 \mathrm{mg} / \mathrm{kg}$ ALA was given intraperitoneally for three days, and its effects were examined. Their microscopic examination revealed normal colonic epithelium and mor- 
phology in their control group, severe loss of surface epithelium, degeneration of crypts, distortion in lamina propria, severe submucosal edema, vasculitis, and severe inflammatory cell infiltration in all layers in their sham group. ALA groups revealed the presence of normal epithelium and crypts, mild submucosal edema, inflammatory cell infiltration, and vasculitis. In a more recent study by Sun et al. ${ }^{(30)}$, ALA was determined to have positive effects on colonic wall thickening, increased inflammatory cell infiltration, and decreased number of goblet cells in the mucosa. They claimed that ALA improved normal intestinal structure. In our study, we found significant improvement in ALA Gavage Group regarding morphological changes, in accordance with these studies. There were no statistically significant differences between ALA Gavage Group and Control Group regarding total microscopic and macroscopic lesion scores. The effect of ALA was observed to be very good on the mucosa; no ulcerated mucosa was found in any specimen (scores were equal with Control Group). Compared with Sham Group, macroscopic scores and significant improvement in serum MDA values suggest that this treatment is effective in colitis. We can explain the similar results with these studies based on the systemic effect of ALA given in these experimental models.

Kim et al. ${ }^{(31)}$ claimed that locally effective anti-inflammatory drugs used in the treatment of UC had only a limited effect on the area of inflammation in the colon because they were absorbed from the upper gastrointestinal tract. They used a steroid drug in combination with a special supplement, and showed that this drug exerted its effect in the colon. One of their recommendations was the production of colon-specific forms of such drugs used in the treatment or using drugs by rectal administration. As examples of the effectiveness of local intracolonic treatments, Dundar et al. ${ }^{(32)}$ with origanum onites oil, Butzner et al. ${ }^{(33)}$ with butyrate, and Chen et al. (34) with muscovite, have reported successful results on colitis following intracolonic administration.
We were unable to find any study related to the intracolonic administration of ALA. In the light of the above studies, we expected ALA administered as an enema, would affect the colonic mucosa directly in contact, and after absorption, it would also have a systemic healing effect. However, we saw that there was a significant difference between ALA Enema Group and Control Group regarding total macroscopy and microscopy scores, but no difference with Sham Group. Therefore, our findings in ALA Enema Group and our prediction about the results of the study were not in accordance with the literature.

The reduction of ALA to its more potent metabolite DHLA is dependent on the enzymes contained in the cell ${ }^{(35)}$. Podda et al. ${ }^{(36)}$ gave mice a total of $1.65 \mathrm{~g} / \mathrm{kg}$ exogenous ALA, which was transported to the tissues and reduced to DHLA. The enzymes that reduce ALA in the cell are NADH-dependent cellular mitochondrial dihydrolipoamide reductase in tissues and NADPH-dependent cytosolic glutathione reductase enzyme in non-mitochondrial cells such as erythrocytes ${ }^{(37)}$. Therefore, the effect of ALA is increasing in cells containing mitochondria and may be transported to the region with erythrocytes in case of its oral intake ${ }^{(35)}$. Oxidant defense mechanisms such as superoxide dismutase, catalase, glutathione, and peroxidases have been shown to be less effective in the colon compared to the liver ${ }^{(38)}$. Therefore, if ALA can be transported sufficiently into the cell, it will show its most potent effect. In our study, the reason for the strong systemic antioxidant effect of ALA despite its failed local effect might be due to the decreassed absorption of ALA secondary to the thick mucus layer formed on the intestinal epithelium because of the inflammation, decreased colonic absorption due to mucosal damage, and the increased colonic passage due to diarrhea. Previous reports revealed a reduction in MDA levels with its use for its anti-inflammatory or antioxidant activities in colitis (39). There was no difference between Control Group and the ALA Enema Group regarding MDA, catalase and NO values, like the relation between Control 
Group and Sham Group. In ALA Enema Group, MDA level was reduced compared to Sham Group; however, it did not reach the level of statistical significance. Considering that as a biochemical parameter MDA levels increase with oxidative stress, we think that ALA given by enema can be partially reduced in cases with colitis. This assumption may be tested with a significantly higher number of subjects.

\section{CONCLUSION}

In our study, we determined the positive effects of ALA on histopathological and biochemical values in the experimental colitis model where ALA was administered via the upper gastrointestinal tract. We have the opinion that ALA, which is a proven potent antioxidant, might be helpful in maintaining remission in patients with IBD. Regarding its other probable clinical benefits, we also suggest that it might be helpful in reducing the incidence of postoperative enterocolitis in patients with Hirschsprung or it may be used prophylactically for the prevention of necrotizing enterocolitis in premature newborns. Further experimental and clinical studies are needed for discovering such beneficial effects of ALA.

Ethics Committee Approval: The study was conducted after obtaining permission from the Adnan Menderes University Animal Research Ethics Committee (No:11/2006-112).

Conflict of Interest: The authors have no conflict of interest. Funding: This study was supported by the Scientific Research Fund of Adnan Menderes University.

Etik Kurul Onayı: Çalışma Adnan Menderes Üniversitesi Hayvan Deneyleri Etik Komitesi izni ile yapılmıştır (No:11/2006-112).

Çıkar Çatışması: Yazarlar tarafindan çıkar çatışması bildirilmemiştir.

Finansal Destek: Çalışma Adnan Menderes Üniversitesi Bilimsel Araşttrma Projeleri Fonu tarafindan desteklenmiştir.

\section{REFERENCES}

1. Podolsky DK. Inflammatory bowel disease. N Engl J Med. 2002;347(6):417-29. [CrossRef]
2. Shih DQ, Targan SR. Immunopathogenesis of inflammatory bowel disease. World J Gastroenterol. 2008;(3)14:390-400. [CrossRef]

3. Sartor RB. Mechanisms of disease: pathogenesis of Crohn's disease and ulcerative colitis. Nat Clin Pract Gastroenterol Hepatol. 2006;3(7):390-407. [CrossRef]

4. Khor B, Gardet A, Xavier RJ. Genetics and pathogenesis of inflammatory bowel disease. Nature. 2011;474(7351):30717. [CrossRef]

5. Carvalho R, Hyams JS. Diagnosis and management of inflammatory bowel disease in children. Semin Pediatr Surg. 2007;16(3):164-71. [CrossRef]

6. Escher JC, Ten KF, Lichtenbelt K, Schornagel I, Buller H, Derkx $B$, et al. Value of rectosigmoidoscopy with biopsies for diagnosis of inflammatory bowel disease in children. Inflamm Bowel Dis. 2002;8(1):16-22. [CrossRef]

7. Irving PM, Gibson PR. Infections and IBD. Nat Clin Pract Gastroenterol Hepatol. 2008;5(1):18-27. [CrossRef]

8. Irving PM, Shanahan F, Rampton DS. Drug interactions in inflammatory bowel disease. Am J Gastroenterol. 2008;103(1):207-19. [CrossRef]

9. Karlen P, Lofberg R, Brostrom O, Leijonmarck CE, Hellers G, Persson PG. Increased risk of cancer in ulcerative colitis: a population-based cohort study. Am J Gastroenterol. 1999;94(4):1047-52. [CrossRef]

10. Biewenga GP, Haenen GR, Bast A. The pharmacology of the antioxidant lipoic acid. Gen Pharmacol. 1997;29(3):315-31. [CrossRef]

11. Bilska A, Wlodek L. Lipoic acid - the drug of the future? Pharmacol Rep. 2005;57:570-7. Available from: http://www. if-pan.krakow.pl/pjp/pdf/2005/5_570.pdf.

12. Karakoyun B, Yuksel M, Ercan F, Erzik C, Yegen BC. Alphalipoic acid improves acetic acid-induced gastric ulcer healing in rats. Inflammation. 2009;32(1):37-46. [CrossRef]

13. Sharma M, Gupta YK. Effect of alpha lipoic acid on intracerebroventricular streptozotocin model of cognitive impairment in rats. Eur Neuropsychopharmacol. 2003;13(4):241-7. [CrossRef]

14. Wengrower D, Zanninelli G, Pappo O, Latella G, Sestieri M, Villanova A, et al. Prevention of fibrosis in experimental colitis by captopril: the role of tgf-beta1. Inflamm Bowel Dis. 2004;10(5):536-45. [CrossRef]

15. Ek RO, Serter M, Ergin K, Yildiz Y, Cecen S, Kavak T, et al. The effects of caffeic acid phenethyl ester (CAPE) on TNBSinduced colitis in ovariectomized rats. Dig Dis Sci. 2008;53(6):1609-17. [CrossRef]

16. Peran L, Camuesco D, Comalada M, Nieto A, Concha A, DiazRopero MP, et al. Preventative effects of a probiotic, Lactobacillus salivarius ssp. salivarius, in the TNBS model of rat colitis. World J Gastroenterol. 2005;11(33):5185-92. [CrossRef]

17. Bell CJ, Gall DG, Wallace JL. Disruption of colonic electrolyte transport in experimental colitis. Am J Physiol. 1995;268(4 Pt 1):G622-30. [CrossRef]

18. Ohkawa H, Ohishi N, Yagi K. Assay for lipid peroxides in animal tissues by thiobarbituric acid reaction. Anal Biochem. 1979;95(2):351-8. [CrossRef]

19. Aebi H, Bergmeyer HU. Methods of enzymatic analysis. Birmingham: Academic Press; 1974. p. 673-677. [CrossRef]

20. Cortas NK, Wakid NW. Determination of inorganic nitrate in serum and urine by a kinetic cadmium-reduction method. Clin Chem. 1990;36(8 Pt 1):1440-3. Available from: http:// clinchem.aaccjnls.org/content/clinchem/36/8/1440.1.full. pdf. 
21. Kucharzik T, Maaser C, Lugering A, Kagnoff M, Mayer L, Targan S, et al. Recent understanding of IBD pathogenesis: implications for future therapies. Inflamm Bowel Dis. 2006;12(11):1068-83. [CrossRef]

22. Beattie RM, Croft NM, Fell JM, Afzal NA, Heuschkel RB. Inflammatory bowel disease. Arch Dis Child. 2006;91(5):42632. [CrossRef]

23. Kawada M, Hachiya $Y$, Arihiro A, Mizoguchi E. Role of mammalian chitinases in inflammatory conditions. Keio J Med. 2007;56(1):21-7. [CrossRef]

24. Sartor RB. Intestinal microflora in human and experimental inflammatory bowel disease. Curr Opin Gastroenterol. 2001;17(4):324-30. Availablea from: https://journals.Iww. com/co-gastroenterology/pages/articleviewer.aspx?year $=20$ $01 \&$ issue $=07000 \&$ article $=00005 \&$ type $=$ abstract .

25. Laukoetter MG, Nava P, Nusrat A. Role of the intestinal barrier in inflammatory bowel disease. World J Gastroenterol 2008;14(3):401-7. [CrossRef]

26. Wirtz S, Neufert C, Weigmann B, Neurath MF. Chemically induced mouse models of intestinal inflammation. Nat Protoc. 2007;2(3):541-6. [CrossRef]

27. Jurjus AR, Khoury NN, Reimund JM. Animal models of inflammatory bowel disease. J Pharmacol Toxicol Methods. 2004;50(2):81-92. [CrossRef]

28. Torres MI, Garcia-Martin M, Fernandez MI, Nieto N, Gil A, Rios A. Experimental colitis induced by trinitrobenzenesulfonic acid: an ultrastructural and histochemical study. Dig Dis Sci. 1999;44(12):2523-9. [CrossRef]

29. Kolgazi M, Jahovic N, Yuksel M, Ercan F, Alican I. Alpha-lipoic acid modulates gut inflammation induced by trinitrobenzene sulfonic acid in rats. J Gastroenterol Hepatol. 2007;22(11):185965. [CrossRef]

30. Sun J, Zhang H, Guan L, Zhou H, Sun M. Alpha-lipoic acid attenuates trinitrobenzene sulfonic acid-induced ulcerative colitis in mice. Int J Clin Exp Med. 2015;8(1):358-67. Available from: https://www.ncbi.nlm.nih.gov/pmc/articles/PMC4358461/ pdf/ijcem0008-0358.pdf.
31. Kim I, Kong $\mathrm{H}$, Lee $\mathrm{Y}$, Hong $\mathrm{S}$, Han J, Jung $\mathrm{S}$, et al. Dexamethasone 21-sulfate improves the therapeutic properties of dexamethasone against experimental rat colitis by specifically delivering the steroid to the large intestine. Pharm Res. 2009;26:415-21. [CrossRef]

32. Dundar E, Olgun EG, Isiksoy S, Kurkcuoglu M, Baser KH, Bal C. The effects of intra-rectal and intra-peritoneal application of Origanum onites L. essential oil on 2,4,6-trinitrobenzenesulfonic acid-induced colitis in the rat. Exp Toxicol Pathol. 2008;59(6):399-408. [CrossRef]

33. Butzner JD, Parmar R, Bell CJ, Dalal V. Butyrate enema therapy stimulates mucosal repair in experimental colitis in the rat. Gut. 1996;38(4):568-73. Available from: https://www. ncbi.nlm.nih.gov/pmc/articles/PMC1383116/ https://doi.org/10.1136/gut.38.4.568

34. Chen Y, Chen Y, Liu WL, Zhou TH, Cai JT, Du Q, et al. Therapeutic effects of rectal administration of muscovite on experimental colitis in rats. J Gastroenterol Hepatol. 2009;24(5):912-9. [CrossRef]

35. Jones W, Li X, Qu ZC, Perriott L, Whitesell RR, May JM. Uptake, recycling, and antioxidant actions of alpha-lipoic acid in endothelial cells. Free Radic Biol Med. 2002;33(1):8393. [CrossRef]

36. Podda M, Tritschler HJ, Ulrich H, Packer L. Alpha-lipoic acid supplementation prevents symptoms of vitamin E deficiency. Biochem Biophys Res Commun. 1994;204(1):98-104. [CrossRef]

37. Moini H, Packer L, Saris NE. Antioxidant and prooxidant activities of alpha-lipoic acid and dihydrolipoic acid. Toxicol Appl Pharmacol. 2002;182(1):84-90. [CrossRef]

38. Yavuz Y, Yuksel M, Yegen BC, Alican I. The effect of antioxidant therapy on colonic inflammation in the rat. Res Exp Med (Berl). 1999;199(2):101-110. [CrossRef]

39. Zhou YH, Yu JP, Liu YF, Teng XJ, Ming M, Lv P, et al. Effects of Ginkgo biloba extract on inflammatory mediators (SOD, MDA, TNF-alpha, NF-kappaBp65, IL-6) in TNBS-induced colitis in rats. Mediators Inflamm. 2006;2006(5):92642. [CrossRef] 